\title{
The Jesuits and the quiet side of the Scientific Revolution.
}

\author{
Louis Caruana
}

There is little doubt that European intellectual development, in various fields, has been marked by the contribution of Jesuits. The emergence of the natural sciences is no exception. Just three years before the first publication of Nicolaus Copernicus' De Revolutionibus, the Society of Jesus was officially founded in 1540. Eleven years later, we see the beginnings of what eventually became the Roman College, a centre of learning whose influence regarding theology and natural philosophy extended over all Europe and beyond. The Jesuits' apostolic style took shape therefore during the turbulent years of the birth and development of natural science. The scientific revolution has been studied in various ways. Some early accounts favor a so-called Whig interpretation whereby the sequence of events is seen as a steady, victorious march from the age of darkness towards the light. Other, more responsible accounts reconstruct the narrative in terms of paradigm-shifts. In many of these accounts, the Jesuit project in the sixteenth and seventeenth centuries is often portrayed as ending in a tragic failure. Jesuits are depicted as being at first favorable to the new science. There is then the decree from higher authorities that blocks their open attitude; and henceforth they become the major resistance to scientific progress. The result of their opposing efforts in this area is then portrayed as a total failure. ${ }^{1}$ Fortunately, more recent accounts of how science develops are more sophisticated and responsible. Imre Lakatos proposed that our main focus should be on research programs. This idea was certainly a step in the right direction. It invites historians to concentrate first on the core of such projects in terms of theories that are considered indisputable by a specific group of researchers. This core is seen as surrounded by a protective belt of auxiliary hypotheses that explain why the core theories should not be rejected when contradictory evidence arises. The task of researchers is therefore to formulate the simplest, and thus most acceptable, auxiliary hypothesis that saves the core. On this account, perseverance with the core project is of the essence of scientific practice. ${ }^{2}$

My aim in this paper is to work within the framework of this sophisticated version of scientific change so as to gain a deeper understanding of the Jesuits' role in the scientific revolution. Their received research program was Aristotelian cosmology. Their efforts to construct one protective belt after another to shield the core principles involved in this cosmology were fuelled not only by the basic instinct to persevere, as Lakatos describes. It was propelled as well by the impact of official prohibitions from the side of Church authorities that tended to avoid change. The clash between Copernicanism and the Church is marked primarily by three dates. The first condemnation occurred in 1616. This was directed primarily against Copernicanism as a theory. The second, more drastic condemnation occurred in 1633: Copernicanism was declared heretical and Galileo was placed under house arrest. The third significant year was 1757 when the Congregation removed the 1616 decree from the new edition of the Index of forbidden books. This meant that the previous condemnations were effectively, although not officially, withdrawn. The Galileo case

\footnotetext{
${ }^{1}$ For an example of such simplistic historiography, see Andrew D. White, A history of the warfare of science with theology in Christendom (New York: Appleton, 1896; republished Prometheus Books, 1993).

${ }^{2}$ Imre Lakatos, "Falsification and methodology of scientific research programmes," in: I. Lakatos and A. Musgrave (eds.), Criticism and growth of knowledge (Cambridge: Cambridge University Press, 1970), pp. 95-195.
} 
cannot, however, be associated exclusively with these three dates. It has had repercussions along the centuries up to our own times. To situate this paper within reasonable limits, I will concentrate on a period of about a hundred years, starting from the first condemnation of 1616 and ending in the early eighteenth century. My basic assumption will be that the Church restrictions, represented primarily by the two condemnations, were not as paralyzing for Jesuit intellectuals as has often been thought. They left considerable space for maneuvering. Valuable contributions to the debates that were forging the very heart of the emerging new paradigm were still possible. Within this space, Jesuits weren't engaged in spectacular new discoveries. Nevertheless, they exerted an important influence. They were essentially engaged in the indispensable task of exhausting all the potential of Aristotelian cosmology. In this paper, I will show how they did this primarily by trying to build intellectual bridges to ensure coherence between three regions of the cosmological imagination of the time. They struggled first to safeguard coherence between the received Aristotelian view, the new empirical data and everyday experience. The obvious way to save the idea of a stationary earth was to support the proposal of Tycho Brahe, in which planets revolve around the Sun while the Sun itself revolves around a stationary earth. Aware of the mounting evidence against the earth's privileged position, however, they realized that this option was being steadily undermined. Various strategies were therefore adopted. To identify these strategies, I will determine first the exact nature of the restrictions imposed on Jesuit scholars by Church authorities. After this first section, I will identify three prominent strategies evident in Jesuit writings. In the concluding section, these strategies will be briefly evaluated and discussed in the light of the intellectual output of Jesuits in later centuries leading up to our own times. The overall result throws light on how scientific development depends on the space left available by social and political restrictions.

\section{The space available after the prohibitions}

A prohibition is a kind of boundary. It doesn't in itself determine what should be said or taught. It only indicates what shouldn't. The sanctions that proscribed the Jesuits from endorsing Copernicanism did not block their activity completely. Let me first distinguish the situation before the early 1600s from the situation afterwards.

Before the early 1600s, Jesuits were used to three main constraints. These were all included in official documents produced by the Society itself. They were norms about their apostolic style. ${ }^{3}$ The first is found in their own Constitutions, officially approved in 1558. In Part IV we find Aristotle being given uncontested prominence in the kind of formation the Jesuits were meant to have: "In logic, natural and moral philosophy, and metaphysics, the doctrine of Aristotle should be followed, as also the other liberal arts." 4 This shows something of the founder's confidence in the approved doctrine of the time. In various points in the Constitutions, Ignatius had included concessions for different times and places. Many commentators have seen in these concessions his particular wisdom in government. As regards doctrine, however, he had never contemplated the possibility of a new cosmology. For him, Aristotle apparently was to be the only point of reference for the entire Society for ever. The second constraint was an important nuance added to the Constitutions by the third

\footnotetext{
${ }^{3}$ I draw here from Marcus Hellyer, Catholic physics: Jesuit natural philosophy in early modern Germany (Notre Dame: University of Notre Dame Press, 2005).

${ }^{4}$ Ignatius of Loyola, The constitutions of the Society of Jesus and their complementary norms, trans. G.E. Ganss, S.J. (Saint Louis: Institute of Jesuit Sources, 1996), Part IV, Chapter 14, § 3.
} 
General Congregation in 1573. Commenting on the part of the Constitutions just quoted, this Congregation specified that, in philosophy, Aristotle had to be taught not for his own sake but as a support for theology. In this way, the ultimate aim of philosophical studies, which included the study of physics, was made clear. Theologians were given the final word.

The third constraint was more substantial: the 1599 Ratio Studiorum. This document charted the educational policy of the rapidly growing Jesuit colleges across Europe. It took some years to compile because it was the result of deliberation by the fifth General Congregation concluded in 1593. It is worthwhile highlighting this Congregation's groundwork before referring directly to the Ratio itself. In Decree 56 of the Congregation, we find the following significant directives:

1) By all means, Ours should consider St. Thomas as their special teacher, and they should be obliged to follow him in scholastic theology, first, because our Constitutions commend this to us in $\S 1$ of chapter 14 of Part 4 and the supreme pontiff, Clement VIII, has indicated that he desires it; and second, because letter $\mathrm{K}$ of chapter 1 of part 8 of the Constitutions admonish us to select the doctrine of one writer, and at this time there can hardly be a doctrine more solid and safe. St. Thomas is deservedly regarded by all as the prince of theologians.

2) Nonetheless, Ours are not to be understood as being so bound to St. Thomas that they may not deviate from him in any respect. For those very ones who most strongly profess themselves to be Thomists differ from him at times. And it is not fitting that Ours be more tightly bound to St. Thomas than are the Thomists themselves.

3) In questions that are purely philosophical and also in those pertaining to Scripture and the canons, it will also be permissible to follow others who have professedly been engaged in those areas. ${ }^{5}$

Following these directives, those responsible for the final version of the Ratio summarized the issue in the following clear mandate:

Teachers of philosophy should not depart from Aristotle in matters of any moment unless there happens to be something foreign to the teaching that academics everywhere approve or, even more so, if there is question of a teaching that is contrary to the orthodox faith. If there are any arguments of this or another philosopher against the faith, they should strongly endeavor to refute them, in accord with the Lateran Council. ${ }^{6}$

The Jesuits were aware of the possibility of finding elements in the Aristotelian corpus that go against the faith. Moreover, they saw themselves not as innovators, called to explore new intellectual territory, but as followers of the general trend of responsible scholars. For a deviation from Aristotle to be acceptable, the basic criterion was to wait until the debate subsides. Jesuit scholars were then expected to adopt the opinion of the majority. Although this looks very much like a conservative

\footnotetext{
5 J.W. Padberg S.J., M.D. O’Keefe S.J., and J.L. McCarthy S.J., For matters of greater moment: the first thirty Jesuit general congregations (St. Louis: Institute of Jesuit Sources, 1994), p. 207. Surprisingly, point 1 of this official text of the Congregation misquotes the Constitutions. The point indicated by the letter $\mathrm{K}$ doesn't in fact deal with following a single author but a single doctrine. Moreover, although point 2 shows an opening towards some diversity, it is still centered on Thomistic interpretation. The scientific revolution did not fit into this model. The stationary earth had been defended by Aristotle in De caelo 2.13.293b.16-32 and 2.14.296a.24-26; and by Aquinas in his commentary on De caelo.

${ }^{6}$ Cf.: Padberg et al., p. 199. The $5^{\text {th }}$ Lateran Council (1512-1517) had decreed that, in the search for truth, faith should be given priority over the exercise of reason.
} 
strategy, one needs to recall that, at that time, the Ratio was overall a courageous, innovative document. ${ }^{7}$ It allowed even for disagreement with Aquinas: "one is never to talk of St. Thomas without honoring him, following him willingly whenever possible; one is to depart from him with reverence and reluctance." 8

These three factors determined the Jesuit frame of mind as the new cosmology was on the verge of sweeping across Europe. The second phase of prohibitions can be seen as starting after the early 1600s. As Rome went through the Galileo crisis, the Vatican condemned Copernicanism in 1616 and then, in 1633, declared it heretical, placing Galileo under house arrest. Another prohibition arose from the Jesuit authorities themselves, who wanted to update their position after the Vatican decision. Their official statement was the Ordinatio pro studiis superioribus of 1651, one of the fruits of the Ninth General Congregation. This was practically a list of philosophical and theological opinions declared forbidden in Jesuit teaching. The main idea was that Aristotle and Aquinas had to be given pre-eminence, and that the most common opinion should be adhered to. In spite of this conservative attitude, we find yet again that some doors were left open. Some points that had seemed certain about thirty-five years earlier were not included. For instance the fluidity of the heavens had been considered an unacceptable opinion. The Ordinatio never included this in its list. It implied thereby that, even though fluidity contradicts Aristotle's theory of solid spheres, it could be taught if ever it became the more common opinion.

These prohibitions had various effects on Jesuits. ${ }^{9}$ In general, the pronouncements of the Roman Inquisition, set up in 1542, had high authority even though they lacked the status of infallible teaching. The Jesuit Giovanni Battista Riccioli in his Almagestum Novum (1651), described the moral obligation imposed on Catholics by the 1633 condemnation:

As there has been no definition on this matter by the Sovereign Pontiff or by a General Council directed and approved by him, it is in no way of faith that the sun moves and the earth is motionless; ... Still, all Catholics are obliged ... at least not to firmly teach the opposite of what the decree lays down $(\&$ saltem ad non docendum absolute oppositum) ${ }^{10}$

Strictly speaking, the Roman Inquisition had the authority to exercise its powers in all Catholic countries except Spain, which had its own Inquisition. In practice, however, it had no power outside Italy. Sovereigns of France and of Germanic lands, even though Catholic, would not tolerate interference from Rome. There was always the

\footnotetext{
${ }^{7}$ Critics of the Jesuits submitted the Ratio to the Inquisition twice. See J. Consentino, "Le matematiche nelle "Ratio Studiorum" della Compagnia di Gesù" in: Miscellanea Storica Ligure II/2 (1970): 171213.

${ }^{8}$ Ratio Studiorum, para. 6 [212]. Note that Jesuit Thomism is not equivalent to Dominican Thomism. See Rivka Feldhay, "Knowledge and salvation in Jesuit culture," Science in Context 1 (1987): 195213; in her judgment (p. 201), "Jesuit Thomism, in comparison with Dominicans', was mainly distinguished by its particular openness, stemming from the Jesuits' quest to educate the entire Catholic secular elite on the one hand, and from the independent intellectual interest developed by the second generation of scholars, on the other hand." See also Francis Winterton, "Philosophy among the Jesuits", Mind 12 (1887): 254-74; Steven J., Harris, "Transposing the Merton thesis: apostolic spirituality and the establishment of the Jesuit scientific tradition," Science in Context 3 (1989): 29-65.

${ }^{9}$ I have not exhausted all the prohibitions. For more cases of censorship, see: Richard J. Blackwell, Galileo, Bellarmine and the Bible (Notre Dame: University of Notre Dame Press, 1991), p. 149; M-P Lerner, "L'entrée de Tycho Brahe chez les jésuites, ou le chant du cygne de Clavius" in: Luce Giard (ed.), Les jésuites à la Renaissance: système éducatif et production du savoir (Paris: Presses Universitaires de France, 1995), pp. 145-86.

${ }^{10}$ Giovanni Battista Riccioli, Almagestum novum (Bononiæ: Ex typographia hæredis Victorij Benatij, 1651), Tome 1, Liber Secundus, Caput III, Scholia, p. 52.
} 
possibility that the Roman authorities impose spiritual sanctions such as excommunication on offenders beyond the Italian peninsula, but they never in fact did so in the case of Copernicanism. ${ }^{11}$

In brief then, the constraints on the Jesuit intellectual output in the latter half of the seventeenth century were of various kinds. Whatever the reasons behind them, they did leave some space for maneuvering. They obliged the Jesuits to trace a risky path across slippery intellectual territory. Jesuits were obliged to refute Copernicanism. They felt obliged also, for the sake of intellectual integrity, to accept genuine evidence when they saw it. They wanted to avoid both useless speculation and uncritical revisionism. How did they manage all this?

\section{Probability arguments}

The first Jesuit strategy worth highlighting involves the question of certainty. Endorsing or defending Copernicanism wasn't an option. This ban, however, did not forbid anyone from discussing and evaluating the probability of the claims of heliocentrism. Taking this opportunity, Jesuits started to slide away from an attitude of clear-cut distinctions between truth and falsity, as was fashionable in high scholasticism. They embarked on a more subtle discussion of the merits of the different, contesting hypotheses.

History shows that changes of ideas are never abrupt. New explanations that gain credibility do so gradually: from being regarded as certainly false to being regarded as somewhat possible, then to being regarded as perhaps probable, and finally to being regarded as warranted or true. The main ingredient here is hypothetical reasoning. For medieval schoolmen, such reasoning was an exercise in entertaining ideas that did not fit the accepted system. An absurdity for Aristotelian and Ptolemaic science could nevertheless be entertained. Some explanations started thus to be mentioned and discussed only, as it were, for the sake of the argument. Spelling out the forbidden claim, however, is already a slight concession. It allows a peep at its consequences; and this makes all the difference. The schoolmen were encouraged in this procedure by the theologians' admonition that God's omnipotence cannot be restricted by the limitations of the Aristotelian or Ptolemaic paradigm. The impossibilities of natural philosophy thus became possibilities de potentia Dei absoluta. This is just one illustration of how, if the climate of opinion changes, or if new evidence becomes available, what had been considered anathema could start becoming a possibility. In his discussion on this point, the historian Amos Funkenstein writes:

Even where schoolmen in the Middle Ages traded Aristotle's "impossibilities" for possibilities de potentia Dei absoluta, they regarded them only as incompossible with our universe. With the usage of ideal experiments in the seventeenth century many such incompossibles became limiting cases of our

\footnotetext{
${ }^{11}$ The attitudes of Jesuits depended also on their country: for Germany and Italy see Hellyer, Catholic Physics; for the situation in France, see John I. Russell, S.J., "Catholic astronomers and the Copernican system after the condemnation of Galileo," Annals of Science 46 (1989): 365-86. In France, the effects of the 1633 condemnation weren't uniform. For instance, on the one hand, we find Descartes abandoning the publication of his nearly complete manuscript Le Monde. On the other hand, we find an edition of Galileo's condemned Dialogues published at Lyons in 1641, in defiance of the Index; it even had a formal Imprimatur from the diocesan authorities.
} 
universe; even if they do not describe our universe, they are necessary to explain it. $^{12}$

This offers a good sketch of what the Jesuits did in the aftermath of the Galilean controversy. Constrained to work within the boundaries of the various prohibitions, the Jesuits started by ignoring Copernicanism. They then started included it in textbooks as a false hypothesis. This inclusion allowed it to be described and even sometimes discussed at length. The Jesuits were thus instrumental in making Copernicanism shift from being seen as false because impossible, to being considered possible but improbable, and finally to being considered possible and probable which is just a step away from being considered true. This technique was effective especially after the Ordinatio of 1651. As indicated above, this document obliged Jesuits to stick to Aristotle and Aquinas, but did so in a way that explained how departures from these authors could be made. As a consequence, the imprimatur was also available to those who made a judicious use of "probable" and "hypothesis". Jesuit scholars were thus allowed to publish commentaries on various aspects of the new cosmology even though the official position of the Vatican was against them. This strategy is evident in various works of the time, especially in those published in the German speaking provinces. On this, Marcus Hellyer writes: "Provided Aristotle or St. Thomas' opinion was granted a degree of probability, other opinions could be openly discussed." 13

There are two crucial consequences of the Jesuit use of probability: one concerns biblical interpretation, and the other the role of superiors. The point about biblical interpretation refers to the principle of accommodation. Put simply, this principle stipulates that scripture speaks a human language appropriate, or accommodated, to the mentality of the time. Aquinas spells it out: "Scripture speaks according to the opinion of the people." 14 This is to be distinguished from a related but different idea, often referred to by the term "concordism". This idea concerns a specific way of interpreting the Bible. It stipulates that, whenever well-established empirical evidence stands opposed to some Biblical claim about physical nature, the Bible should be given an appropriate reinterpretation so that its descriptions regain coherence with empirical data. For instance, the six days of creation in Genesis need to be reinterpreted as six, very long periods of time so as to be in line with current views on the age of the universe. Concordism corresponds to a maximalist version of the principle of accommodation as opposed to a minimalist version. ${ }^{15}$ Concordism is maximalist in the sense that the Bible is assumed to contain all science and metaphysics. This content, heavily clothed in metaphors, remains inaccessible to the uneducated masses of the various periods in the course of history. The minimalist version is the exact opposite. The Bible is here assumed neutral as regards physics and metaphysics. It is assumed lacking in significant descriptive content regarding the nature of things. Hence, on the minimalist view, the Bible neither contradicts science nor contains it in a hidden way.

\footnotetext{
${ }^{12}$ Amos Funkenstein, Theology and the scientific imagination from the Middle Ages to the seventeenth century (Princeton: Princeton University Press, 1986), p. 17.

${ }^{13}$ Hellyer, Catholic Physics, p. 46.

${ }^{14}$ Summa Theologiae 1-2, Q 98 a3. The principle goes back to at least Augustine, who argued that God "knows much better than man what pertains by accommodation to each period of time (qui multo magis quam homo novit, quid cuique tempori accommodate adhibeatur)," Aurelius Augustinus, Epistulae, Al. Goldbacher (ed.), Pars III (Vindobonae: F. Trempsky; Lipsiae: G. Freytag, 1904), Epistula 138. 1.5, p. 130.

${ }^{15}$ I draw this distinction from Funkenstein, Theology and the scientific imagination, pp. 213-9.
} 
These various trends were all very important during the Galileo controversy. In his letter to the Duchess Christina, Galileo insisted that, if time were to stand still in the Ptolemaic universe, it is not enough that "the sun in Gideon stand still," as written in Joshua 10, 12. The sphere of the fixed stars must cease to move, as well. Hence, Galileo argued, whether we accept Ptolemy or Copernicus, there is no way of interpreting the biblical text as descriptively responsible. There is no science being clothed by ordinary language here. Whether we follow Ptolemy or Copernicus, the text has to be considered metaphorical. It is clear, therefore, that Galileo was a champion of the minimalist version of the principle of accommodation. His opponents, on the contrary, were crude maximalists, insisting on the supreme relevance of the descriptive content of the biblical text, even when such content was marginal as regards the main point of the text.

With the Jesuits' use of probability arguments, the case for such crude maximalist ideas was considerably weakened. Once they started to include in textbooks Copernicanism as a hypothesis worthy of discussion, the arguments of those who used the Bible against heliocentrism were progressively undermined. Copernicanism underwent the stages mentioned above. From being seen as false because impossible, it started being considered possible but improbable, and finally to being considered possible and probable. Geocentrism underwent the opposite development; and so did the maximalist understanding of Scripture. The idea that the Bible contains hidden but true descriptions of the deep nature of the material world used to be accepted as true. Due to the Jesuits' probability-tinted reasoning, its status started to shift. It gradually came to be considered possible but improbable, until it finally ended up being considered impossible. This is not to say that the descriptive content of Scripture was sloughed off completely. Details of a historical nature, ranging from simple facts, like the fact that Jacob had twelve sons, to specific dates for battles and political changes, were always retained as genuine descriptions. These are central to the message of the text. ${ }^{16}$ Other details, however, found their way into the text only as decorative extras. Cosmological ideas are among these latter. The Jesuits' way of engaging in intellectual work after the Galileo case was instrumental in uncovering the true features of the principle of accommodation, namely as stipulating that God, in his infinite wisdom, had accommodated His message to the various mentalities in the course of history not by adjusting, simplifying and packaging the truths of cosmology but by adjusting and simplifying those of theology.

Apart from these issues regarding biblical interpretation, there is a second significant consequence of the Jesuit recourse to probability arguments. This second consequence concerns the role of superiors. As the new cosmology found its way into textbooks, the evidence in its favor started becoming stronger. Some aspects of the ancient cosmology, like celestial immutability and the reality of qualities, soon became untenable. This made Copernicanism gain credibility. Jesuit natural philosophers started adopting a more positive attitude towards the new cosmology. Since they were constrained to avoid admitting its truth, however, they had to think of a way of presenting the stark incompatibility of the two systems in the very same book. They often did this by shifting the responsibility onto superiors. They practically started putting the blame gently on superiors for not allowing them to draw the obvious conclusions regarding the superiority of the new cosmology. The Jesuit Claude Miliet Dechales, who taught mathematics in Jesuit Colleges in Marseilles and

\footnotetext{
${ }^{16}$ See Robert Bellarmine's letter to Foscarini (12 April 1615) in: Blackwell, Galileo, Bellarmine and the Bible, pp. 265-8.
} 
Lyons in the 1670s, was typical. In spite of his sympathies towards Copernicanism, he still felt obliged to reject it. He applied therefore the last available argument: loyalty to Scripture and the Church. He admits that Copernicus gives the simplest explanation. In the same breath, however, he adds that the Church has to be obeyed. If it were not for the authority of Scripture, he himself would be a Copernican. ${ }^{17}$ Something similar is found in the writings of the Jesuit Melchior Cornaeus (15981665), theology professor at Würzburg University. At one point in his 1657 philosophy textbook, he draws a clear contrast between what he thinks is correct and what his superiors want. The specific question wasn't about the motion of the heavens, but about the reality of the distinct qualities of heaviness and lightness, as prescribed by Aristotelians. Cornaeus writes:

What I have just taught about heaviness and lightness according to the opinion of learned men, I myself have openly taught and held for many years. Now because the authority of my superiors commands something else, I say that it is probable that heaviness and lightness are two positive qualities ... And because authority commands that we subscribe to this opinion, I subscribe and I approve of it. ${ }^{18}$

The responsibility is clearly shifted onto Church authorities. The initial discussion on the merits of the various competing hypotheses has resulted in one of the hypotheses becoming much more probable than the other. When the only justification for the old cosmology became superior authority rather than demonstration, the case for the new cosmology became much stronger. As a strategy in managing the cultural tensions of the scientific revolution, this is basically a way of exhausting slowly but steadily the heuristic potential of the received research program.

\section{Anachronistic speculation regarding ancient authors}

Another Jesuit strategy involved addressing questions of this kind: What would the major philosophers of antiquity have said had they been with us today? The form of this question is particularly valuable. It acknowledges the respect due to ancient authorities. It acknowledges moreover the irrefutable value of the new evidence. A very clear example of this strategy can be seen in some arguments presented by Cornaeus. In his textbook mentioned above, he tackles the issue of celestial incorruptibility. Aristotle had repeatedly claimed that the heavens and the stars are immutable and incorruptible. They were made up of the fifth element, the ether. This belief started to be challenged from the late sixteenth century onwards because of various new astronomical observations: comets, sunspots, and hitherto unknown stars or planets. The argument advanced by Cornaeus involved imagining what Aristotle would have said had he been aware of these observations:

If Aristotle had lived today, and had seen how we observe changes and conflagrations in the Sun, without any doubt he would have changed his mind and would have agreed with us. The same reasoning applies to the planets, of which the Philosopher never knew more than seven. We nowadays, however, by the use of the telescope (access to which he never had) know for certain that there are more. ${ }^{19}$

\footnotetext{
${ }^{17}$ See Russell, "Catholic astronomers and the Copernican system after the condemnation of Galileo."

${ }^{18}$ Melchior Cornaeus in his Curriculum philosophiae peripateticae, ut hoc tempore in scholis decurri solet (Würzburg, 1657) 2: 107, quoted in Hellyer, Catholic Physics, p. 51.

${ }^{19}$ Cornaeus, Curriculum, p. 503. This attitude shows a marked shift from the decades preceding the Galileo controversy, when Jesuits used to defend Aristotelian celestial incorruptibility by proposing
} 
What kind of reasoning is involved here? No doubt, Cornaeus presupposes a good knowledge of Aristotle. It is precisely this good knowledge of Aristotle that enables him to go beyond the usual Aristotelian picture. In other words, Cornaeus felt justified in affirming the counterfactual conditional statement: if Aristotle were alive today, he would have agreed that there are changes in the heavens. This is the first step towards a kind of slippery slope. If the statement is true, then it leads to the idea that, if Aristotle had agreed to celestial mutability, he would have seen the need to adjust his entire cosmology. This in turn leads to the more radical claim that, if Aristotle had seen the need to adjust his entire cosmology, he would have become a Copernican. Political correctness demanded that only the first claim be explicitly stated. ${ }^{20}$ The Jesuits were here essentially following the example set by Galileo himself, who at times argued in a similar fashion. In his Dialogue Concerning the Two Chief World Systems, we find him highlighting the importance of sense experience in scientific reasoning. He explicitly states that "we do have in our age new events and observations such that if Aristotle were now alive, I have no doubt he would change his opinion. This is inferred from his own manner of philosophizing." Aristotle's conversion would have resulted, according to Galileo, from the crucial principle of giving priority to sense experience over natural reason. ${ }^{21}$

From these remarks, it is clear that what I'm calling the strategy of anachronistic speculation was a powerful weapon in the hands of those who, like the Jesuits, were open to innovation and yet sought to respect tradition. This strategy was essentially associated with the idea of rediscovering the real Aristotle. Peripatetic doctrine had to be cleaned up from errors that had encrusted upon it since scholastic times. As bits of this peripatetic doctrine were replaced by new ideas and concepts, a variety of systems were tried out. ${ }^{22}$ Such piecemeal replacement and adjustment continued all through the century I'm considering in this paper and even beyond.

\section{Accumulation of Data}

The third and final strategy I want to highlight involves the avoidance of speculation. With evidence in favor of the new cosmology gaining strength, and with

that comets and novae are special divine signs. Cf: William Wallace, Galileo and his sources: the heritage of the Collegio Romano in Galileo's science (Princeton: Princeton University Press, 1984), p. 141.

${ }^{20}$ The idea of celestial incorruptibility was the Achilles heel of the old cosmology. Even those who, decades after Galileo's time, still rejected Copernicanism conceded defeat on the question of the heavens' incorruptibility. One can detect the development in textbooks. For instance, the Jesuit Leonardus Cinnamo is still discussing in $\mathbf{1 7 1 5}$ the question of the incorruptibility of the heavens as a sub-question of whether the heavens are nobler than the earth (see Cinnamo, L., S.J., Microscopium Aristotelicum (Panormi: G. Bayona, 1715), Sec. II, 8). By 1739, the situation changes. In chapter II of a 1739 textbook by Antonio Mayr S.J., entitled Philosophia peripatetica antiquorum principiis, et recentiorum experimentis conformata, Vol. III: Physicae particularis Pars I (Ingolstad), the heavens are taken as indeed corruptible. Mayr even includes biblical evidence for this ( $\$ 847)$.

${ }^{21}$ See Galileo Galilei, Dialogue concerning the two chief world systems, Ptolemaic \& Copernican, trans. S. Drake (Berkeley: University of California Press, 1953), p. 50. See also Wallace, Galileo and his sources, p. 301. The origins of this mature attitude towards Aristotle can be traced back to Albertus Magnus: "Whoever believes that Aristotle was a god, must also believe that he never erred. But if one believes that Aristotle was a man, then doubtless he was liable to error just as we are" (Physica lib. VIII, tr. 1, xiv).

22 This claim is amply justified in E. Grant, Planets, stars, and orbs: the medieval cosmos, $1200-1687$ (Cambridge: Cambridge University Press, 1994); by the late seventeenth century, "bits and pieces of Aristotelian cosmology were replaced by bits and pieces of the new cosmology. Strange cosmological mosaics developed, none of which could win much support" (p. 679). 
the prohibition against Copernicanism still in force, some Jesuit scholars dedicated themselves to sporadic and patchy accumulation of knowledge without any theoretical synthesis. They acknowledged the existence and usefulness of novel ideas and observations, but didn't worry much about the need to ensure a coherent system. This strategy has both negative and positive aspects.

The negative aspects include the fact that, as a research strategy, it tended to engender eclecticism. The clearest example here is Athanasius Kircher (1602-1680), Jesuit professor of mathematics at the Roman College and founder of a renowned museum there. In his Mundus Subterraneus, he just fills pages and pages with descriptions of a bewildering variety of novelties without any coherent synthetic explanation. The novelties he includes strike the modern reader for their sheer variety, ranging from useful geological or biological descriptions to useless folklore. It is difficult not to agree with William B. Ashworth, Jr. who admits that the Jesuits "do indeed seem to merit the praise they have frequently received. And yet when all this is said and acknowledged, there still remains the unavoidable feeling that Jesuit science was somehow seriously deficient." The main reason for his judgment is Kircher, who "sandwiches descriptions of fossil fish between accounts of gems bearing the images of cities and stones in the shape of John the Baptist, and he can sustain such a mélange for hundreds of pages. There is no suggestion that some authorities might be more reliable than others; every fact or observation seems to be given equal weight." 23 Traces of eclecticism can be seen even in Riccioli's Almagestum, especially where he discusses new stars. He lists fourteen possible explanations for their appearance, together with advantages and disadvantages of each. ${ }^{24}$ He doesn't, however, make any attempt to choose one of these explanations. He gives the impression that trying to arrive at the correct one was not really important. In his judgment, the time was apparently not ripe for taking the risk of suggesting a philosophical superstructure for all the facts available. He, like Kircher and others who adopted this strategy, limited himself to gathering information. He postponed the task of establishing explanatory coherence to future generations.

This is a negative aspect is counterbalanced by at least one significant, positive aspect: the beneficial shift of attention from theory to observation. The very meaning of the term "observation" was changing during the scientific revolution. In scholastic natural philosophy, "experience" had taken the form of universal statements. This was because statements of singular events were not evident and indubitable, but relied on fallible historical reports. Peter Dear explains:

In a sense, the Aristotelian model of a science adopted by the Jesuits implied that scientific knowledge must be public - the conclusions of scientific demonstration would in principle be truths perfectly graspable by all, because they were derived from necessary, logical connections between terms formulated in premises commanding universal assent. Singular experiences

\footnotetext{
${ }^{23}$ William B. Ashworth, Jr., "Catholicism in Early Modern Science" in: D.C. Lindberg \& R.L. Numbers (eds.), God and nature: historical essays on the encounter between Christianity and science (Berkeley, Los Angeles: University of California Press, 1986), pp. 136-66; quotations from p. 155. On Kircher's style, see: Paula Findlen, "Scientific Spectacle in Baroque Rome: Athanasius Kircher and the Roman College Museum" in: Mordechai Feingold (ed.), Jesuit science and the Republic of Letters (Cambridge Mass. - London: MIT Press, 2003), pp. 225-84.

${ }^{24}$ Riccioli, Almagestum, Tome II, Libri VIII, Secio II, caput XVII, pp. 174-7.
} 
were not public, but known only to a privileged few; consequently, they were not suitable elements of scientific discussion. ${ }^{25}$

In the early seventeenth century, Jesuit scholars started to include singular experience. Their work enhanced the status of discrete events, which thus started to have a role as properly accredited knowledge about the world. The Jesuits worked essentially to establish two crucial elements in the chain of justification. Private, singular, actual experience was related to public, potential experience; and this public, potential experience was related to universal, self-evident truths. Thus, habitual private experience, which roughly corresponds to the modern understanding of "experiment", started to gain its importance in scientific demonstrations. The hunt for more and more evidence became the central issue. One can see, therefore, how the pressure of the Roman Inquisition did not stifle the development of science in Catholic countries but redirected its attention. It made scientists shift from theory construction to collection of data. Jesuit astronomers, for instance, shifted from theoretical to observational astronomy. Some of them were quite successful in this area: Riccioli and Grimaldi, because of this new shift, managed to map the surface of the moon with remarkable accuracy. ${ }^{26}$

\section{Conclusion}

My original aim was to show how, all along the century following Galileo's first condemnation, Jesuit scholars were, in spite of everything, engaged in genuine science. The prohibitions originating from the Vatican and from their own Jesuit Curia did leave some valuable space for maneuvering. Exhausting all the potential of the received research program was still possible. Of the various strategies in this endeavor, I highlighted three: the introduction of probable judgments in natural philosophy; anachronistic speculation of what ancient authorities would have done had they been faced with the new evidence; and the simple accumulation of data. The fact that Jesuits' research program turned out to be regressive doesn't show that their efforts were unscientific. Once the idea of a crucial experiment, as a gestalt switch between paradigms, is rejected as completely unrealistic, we must acknowledge the importance of perseverance within a given research program. It is a vital constituent of genuine scientific method. Seen in this light, the common assumption that seventeenth century Jesuits were blinkered, reactionary Aristotelians, keen on blocking at all costs the advance of natural science, loses all its plausibility.

Can these strategies help us understand the intellectual output of Jesuits in later centuries? If we start with the major Jesuit figure dominating the period just after the period covered in this paper, Ruder Bošković (1711-1787), we find similar efforts being made even though Aristotelian cosmology was by then quite evidently a regressive research program. Bošković started as a defender of Tycho Brahe's system but soon became convinced that Newtonianism should substitute peripatetic natural philosophy. His main concern was centered on saving the everyday experience of an immobile earth. So he devised his impressive theory of the two kinds of space: a relative space in which the Earth is in motion as described by Newton and an absolute space in which the Earth stands still. By his time, the balance of probabilities in

\footnotetext{
${ }^{25}$ Peter Dear, "Jesuit mathematical science and the reconstitution of experience in the early seventeenth century," Studies in the History and Philosophy of Science 18 (1987): 133-75 (the quote is from p. 143).

${ }^{26}$ Cf. Russell, "Catholic astronomers and the Copernican system after the condemnation of Galileo." By 1773, of the world's 130 astronomy observatories, thirty were operated by Jesuits. There are now thirty-five lunar crators named in honor of Jesuit scientists.
} 
cosmology had tilted definitely towards heliocentrism. Anachronistic reasoning involving ancient authors had become largely irrelevant. In spite of this, Bošković can be seen as engaged in work that was still in line with the broad Jesuit effort of exhausting all the potential of a received research program before discarding it. $\mathrm{He}$ was effectively still stretching out to its limits the idea of the immobility of the Earth as suggested by daily experience. ${ }^{27}$

A similar stance can be seen in Jesuit scientific work through much of the eighteenth, nineteenth and twentieth centuries. Two of the major highlights in this later period were the rise of evolutionary biology and the advances in astronomy. The way Jesuits have been involved in these two areas shows a similar concern to explore all the possibilities before moving on, and a concern to accumulate data. ${ }^{28}$ Innovation and revolutionary thinking is never valued in and for itself. On the contrary, the main concern seems to be safeguarding the coherence of a unified system of thought ranging from science to philosophy and theology. It is not surprising that the need to resist the fragmentation and eventual disintegration of knowledge has been expressly recalled by recent Generals. ${ }^{29}$

This style of work situates its protagonists inevitably on the quiet side of scientific revolutions. For historians, the tendency is to keep the harbingers of new successful research programs in the limelight. Less attention is given to those who do the spadework to ensure that a genuine revolution is called for. Both roles, however, are indispensable for scientific practice. Jesuit scientists have tended to take the latter. ${ }^{30}$

\footnotetext{
${ }^{27}$ See Žarko Dadić, "Bošković and the question of the earth's motion," in The Philosophy of Science of Ruder Bošković, I. Macan and V. Pozaic (eds.), (Zagreb: Institute of Philosophy and Theology, 1987).

${ }^{28}$ See B. Brundell, "Catholic Church politics and evolution theory, 1894-1902," British Journal of the History of Science 34 (2001), pp. 81-95; S. Maffeo, The Vatican Observatory: in the service of nine Popes, trans. G.V. Coyne (Notre Dame: University of Notre Dame Press, 2001).

${ }^{29}$ On the fragmentation of knowledge, see P. Arrupe, "Theological reflection and interdisciplinary debate" in: Pedro Arrupe, S.J., Jesuit apostolates today, J. Aixala S.J. (ed.) (Institute of Jesuit Sources: St. Louis USA, 1981), pp. 33-42; "The intellectual apostolate in the Society's mission," Ibid., pp. 11126. See also, Peter-Hans Kolvenbach, "The Jesuit university in the light of the Ignatian charism," Address to the International Meeting of Jesuit Higher Education, Rome, 27 May, 2001 (available on the internet at http://users.online.be/ sj.eur.news/doc/univ2001e.htm).

${ }^{30}$ Acknowledgements: Pontifical Gregorian University Library, Rome, for professional help in the Rare Books Section; Dr. Michael Hoskin for useful comments.
} 